\section{The relationship between the density of flies and the man- agement of livestock waste with the incidence of diarrhea in the community of dairy farmers in Pudak Kulon Village, Ponorogo, Indonesia}

\author{
Dhia Irfan Hanif, Santi Martini \\ Faculty of Public Health, Universitas \\ Airlangga, Surabaya, Indonesia
}

\begin{abstract}
Diarrhea is still one of community health problems in the world, especially in developing countries such as Indonesia, because of its high morbidity and mortality rates. This study aimed to know the relationship between the density of flies and livestock waste management with the incidence of diarrhea in the community dairy farmers. This study used a descriptive analytic with cross sectional study design. Data was collected using questionnaires, observation sheets, and measurements of the density of flies with a fly method grill and hand counter. Sample research used is as many as 177 family dairy farmers with the sampling method of cluster random sampling. The results of Chi Square test showed a significant relationship between the density of flies with the incidence of diarrhea $(p=0.00)$ and the existence of a significant relationship between livestock waste management with the incidence of diarrhea $(p=0.00)$. It is recommended that dairy farmers could improve their healthy living behaviours and manage the livestock waste.
\end{abstract}

\section{Introduction}

Diarrhea is a condition where a person defecates with soft or liquid consistency, with a frequency of three or more times per day or more often than normal people. ${ }^{1}$ Diarrhea is still one of community health problems in the world, especially in developing countries such as Indonesia, because of its high morbidity and mortality rates. According to the data from the Ministry of Health of Indonesia (Kementerian Kesehatan RI) in 2011, diarrhea was the 13th cause of death with a proportion of $3.5 \% .^{2}$ The environment holds the greatest influence on health. ${ }^{3}$ The causes of diarrheal diseases include community characteristics and environmental health.

According to Pudak Health Center data in 2015, the incidence of diarrhea in Pudak Kulon Village is higher than the average of other villages in Pudak District, Ponorogo in 2015, in which 104 cases and 38 cases occurred in children under five years old. ${ }^{4}$ Pudak Kulon Village has environmental problems related to the number of farmers in the region. Pudak Kulon Village is the region with the most population of breeders, which is 365 families. The management and utilization of non-sanitary livestock waste can be the right medium for diarrhea vectors, which is flies.

Flies are mechanical vectors of various diseases. $^{5}$ Mechanical vectors are invertebrate animals that transmit diseases without accompanied by changes in agents. ${ }^{6}$ The higher the level of fly density, the higher the probability of the spread of diarrhea. This is consistent with research conducted by Manulu in 2012 regarding the relationship between fly density and incidence of diarrhea in children under five years old who live around Namo Bintang Waste Disposal Site, Pancur Batu District, Deli Serdang City. ${ }^{7}$ The study showed that the rate of fly density at a toddler's home had a significant relationship with the incidence of diarrhea.

Based on the description of the incidence of diarrhea in Indonesia, especially in Pudak Kulon Village, Pudak Subdistrict, Ponorogo, and related risk factors for diarrhea, which is environmental conditions, the general purpose of this study is to determine the relationship between the incidence of diarrhea and fly density and livestock waste management in dairy farmers in Pudak Kulon Village, Pudak Subistrict, Ponorogo.

\section{Materials and Methods}

This study was an observational study using descriptive analytic with cross sectional study design. The study was conducted in January-March 2017, in Pudak Kulon Village, Pudak Subdistrict, Ponorogo. The study population is a family of dairy farmers in Pudak Kulon Village, with the total of 365 families. The sample in this study is the family of farmers who maintain dairy cows in their home environment. The sample size in this study used the formula obtained a minimum number of samples of 177 respondents. ${ }^{8}$ The technique used in sampling is cluster random sampling. The technique sampling was chosen by considering the geographical
Correspondence: Dhia Irfan Hanif, Faculty of Public Health, Universitas Airlangga, Jl. Mulyorejo, Surabaya, Jawa Timur 60115, Indonesia.

Tel.: +62315920948 - Fax: +62315924618 E-mail: dhia.fan.hanif-2018@fkm.unair.ac.id

Key words: density of flies, livestock waste management, diarrhea, dairy farmers.

Acknowledgments: the authors gratefully acknowledge all the man who volunteered for this study. We extend our gratitude to the various heads of the Pudak Subdistrict Health Center for granting authorization to access the health centers and all the staff of Pudak Kulon Village government. Special thanks to the data collectors for their involvement in the present study

Contributions: the authors contributed equally.

Conflict of interest: the authors declare no potential conflict of interest.

Funding: none.

Clinical trials: this study didn’t involve any clinical trials.

Conference presentation: part of this paper was presented at the $3^{\text {rd }}$ International Symposium of Public Health, 2018 October 31 - November 1, Universitas Airlangga, Surabaya, Indonesia.

Dedication: the article is dedicated to Faculty of Public Health, Universitas Airlangga.

Received for publication: 28 July 2019.

Revision received: 9 September 2019.

Accepted for publication: 15 October 2019.

This work is licensed under a Creative Commons Attribution NonCommercial 4.0 License (CC BY-NC 4.0).

(C) Copyright: the Author(s), 2019

Licensee PAGEPress, Italy

Journal of Public Health in Africa 2019; 10(s1):1176 doi:10.4081/jphia.2019.1176

unit, which is the division of Rukun Warga (RW) as the basis for the division of clusters/groups.

The instrument of the research used questionnaires, observation sheets, and fly density calculators, which is fly grill and hand counter. The data was collected through interview techniques, measurement and observation. Data processing includes: 1) data editing, 2) data coding, 3) data entry, and 4) data cleaning. Data analysis was carried out in the form of univariate analysis and bivariate analysis using chi square test. 


\section{Results}

The following is the result of processing respondents-data from a total of 100 respondents who participated in the study, including:

\section{Overview of diarrhea incidence}

The results of the study of the incidence of diarrhea within the last three months from the data collection are shown in Figure 1. The results of the analysis of the distribution of diarrhea in dairy farmers are shown in Figure 1, in which there were 68 families $(38.4 \%)$ had experienced diarrhea while the other 109 families $(61.6 \%)$ have never experienced diarrhea.

\section{Overview of flies density}

Results of the study were the measurements of fly density in dairy cattle cages using fly grill according to Table 1 .

Based on Table 1, it can be seen that most of the houses that maintain dairy cattle has a low fly density of 86 houses or $48.6 \%$ of the total respondents, for homes with medium fly density (3-5 tails) reaching 39 houses, 35 houses with high fly density (620 tails) and 17 houses.

\section{Livestock waste management description}

Description of the distribution of livestock management in Pudak Kulon village in this study can be seen in Table 2.

Based on Table 2, it is known that most farmers (60.5\% or 107 respondents) did not manage their livestock waste properly, while 70 farmers $(39.5 \%)$ managed their livestock waste well.

\section{The relationship between diarrhea and flies density}

Results of statistical tests using chi square regarding the relationship between the incidence of diarrhea and the density of flies are described in Table 3.

From the chi square test results with low fly density as compared to the comparison found in Table 3, it can be seen that there is a significant relationship between fly density which is very high with high fly density with the incidence of diarrhea (Pvalue<0.05). Meanwhile, the density of flies is not related to the incidence of diarrhea (Pvalue $<0.05$ ). The denser the fly population, the more significant the relationship with the incidence of diarrhea so that the risk of getting diarrhea becomes greater, as evidenced by the greater value of the Prevalence Ratio (PR).

\section{Relationship between diarrhea and livestock management}

Statistical test results using the chi square regarding the relationship between the incidence of diarrhea and livestock waste management are described in Table 4.

Based on the results of the study in Table 4, there is a significant relationship between the incidence of diarrhea and waste management (value $<0.05$ ) with a value of $\mathrm{PR}=3.59$, which means that farmers who did not carry out waste management properly have 3.59 times more risk to get diarrhea.

\section{Discussion}

\section{Overview of diarrhea events}

Based on the results of the study, there

were $38.4 \%$ or 68 respondents who experienced diarrhea within the last three months since the data collection was conducted. The incidence of diarrhea in this study is known by a questionnaire containing questions about the definition of diarrhea. Communities of dairy farmers and/or family members are said to have diarrhea if they experience bowel movements more than three times a day with consistency of soft or runny stools. ${ }^{1,2}$

The incidence of diarrhea experienced by dairy farmers in Pudak Kulon Village is acute diarrhea, which is diarrhea which lasts for a day or two, with one symptom of abdominal pain. ${ }^{9,10}$ The incidence of diarrhea experienced by farmers in Pudak Kulon Village is the incidence of diarrhea without the presence of other diseases such as acute gastroenteritis, dysentery and cholera.

Table 1. Density of flies in dairy cattle pens.

\begin{tabular}{lcc}
\hline Flies density & Frequency & Percentage (\%) \\
Very High $(\geq 21$ heads) & 17 & 9.6 \\
Height $(6-20$ head) & 35 & 19.8 \\
\hline Medium (3-5 tail) & 39 & 22.0 \\
Low (0-2 heads) & 86 & 48.6 \\
\hline Total & 177 & 100.0 \\
\hline
\end{tabular}

Table 2. Management of livestock waste in Pudak Kulon Village.

\begin{tabular}{lcc} 
Management of Animal Waste & Frequency & Percentage (\%) \\
No & 107 & 60.5 \\
Yes & 70 & 39.5 \\
Total & 177 & 100.0 \\
\hline
\end{tabular}

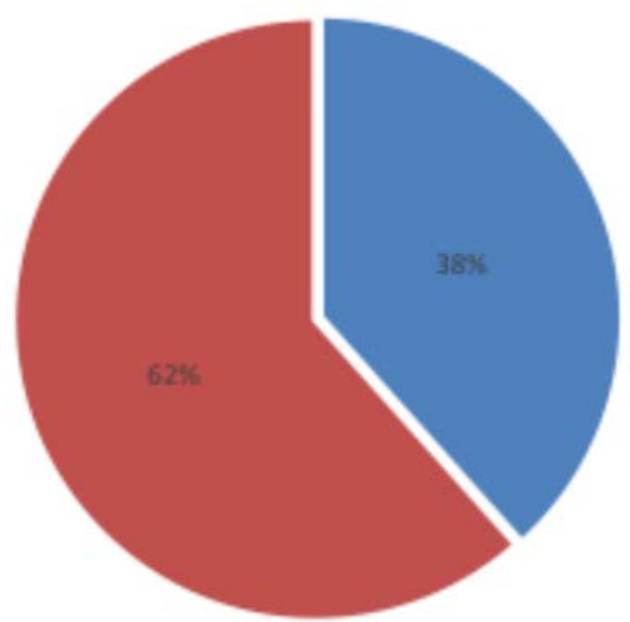

. 68(38.49) Families had experoenced diarrhea

- 109 (61.6\%) Families have never experienced diarrhea

Figure 1. Diarrhea distribution diagram for dairy farmers in the community. 


\section{Flies density overview}

Results showed that there were 17 respondents who had a cage with a very high fly density and 35 respondents with high fly density. The high density of flies in Pudak Kulon Village can be caused by the presence of a cow pens in the home environment with a distance of less than 10 meters ( $92 \%$ of respondents), and livestock waste that is not managed properly $(60.5 \%$ of respondents) making it easier for flies to land at home population.

Low fly density (86 people or $48.6 \%$ respondents) and medium fly density (42 people or $22 \%$ respondents) due to the concentration of food given to cows containing ingredients that can reduce the smell of dirt produced by cows, so interest flies are reduced. In addition, some cages were found in the burning of dried grass left over from cow's milk. The burning can cause smoke. Frying is one of the ways to control fly. ${ }^{5}$

\section{Livestock waste management description}

Most of the houses that maintain dairy cattle do not manage their livestock waste properly (107 respondents or $60.5 \%$ of a total of 177 samples). The large number of breeders who do not manage their livestock waste properly was reviewed from the points of assessment of livestock waste management including the distance of the cage to the house, the condition of livestock manure shelters, the condition of livestock sewage drainage, cleaning of pens, as well as the collection and utilization of livestock waste.

The distance between the cage andhouse is mostly less than 10 meters. Meanwhile, livestock manure shelters $(85.3 \%)$ still have contact with open air so that in addition to causing unpleasant odor, it also disrupts human health. ${ }^{11}$

The condition of the majority of wastewater sewers is not separated from rainwater $(67.2 \%)$ and is not water resistant (75.1\%). This is feared to be the cause of waste water infiltration into the environment, causing pollution and a breeding ground for mosquitoes and flies as disease vectors. ${ }^{12,13}$ In addition, only 72 respondents processed livestock waste into biogas and manure. Whereas, waste processing is important to reduce the amount of waste discharged into the environment. ${ }^{14}$

\section{Relationship between diarrhea and flies density}

Analysis of statistical tests of research results using chi square in Table 4, shows that there is a significant relationship between the incidence of diarrhea with very high fly density and high fly density ( $P$ value $<0.05$ ). In addition, the risk of getting diarrhea is greater if the density of flies is higher.

Biological environments such as disease vectors and environmental conditions with poor sanitation can cause infectious diseases such as diarrhea. ${ }^{15}$ The state of poor sanitation in Pudak Kulon Village is caused by environmental pollution due to livestock waste, even though livestock manure is a breeding ground for flies. ${ }^{5}$ Flies can carry various microbes such as Salmonella spp Shigella spp, Vibrio cholerae and E. coli which are capable of contaminating food and causing diarrhea. ${ }^{16,17}$

The results of this study are in line with the research of Manulu et al. in 2012, concerning the relationship of the density level of flies (Musca domestica) with the incidence of diarrhea in children under five in the settlements around the Namo Bintang waste landfill. ${ }^{7}$ The results of this study indicate a relationship between the incidence of diarrhea and the level of fly density.

\section{Relationship between diarrhea and livestock management}

Analysis of statistical tests using chi square obtained the results of $\mathrm{p}$ value $=$ 0.00 , which indicates that there is a significant relationship between the incidence of diarrhea and livestock waste management in dairy farmers in Pudak Kulon Village. The existence of this relationship was caused by 107 farmers or $60.5 \%$ of respondents did not manage their livestock waste properly.

Biological environments such as certain disease vectors and environmental conditions with poor sanitation can cause infectious diseases such as diarrhea. ${ }^{15}$ Poor sanitation can be caused by environmental pollution due to livestock waste. Based on observations, the majority of the dairy farmers in Pudak Kulon Village drain livestock wastewater (in the form of residual washing from the cage and diluted urine and livestock manure) into the ditch and immediately wasted into the environment without prior treatment. In addition, there are still many breeders, which is around $67.2 \%$ of the respondents

Table 3. Distribution of dairy farmers according to the incidence of diarrhea with the density of flies in Pudak Kulon Village.

\begin{tabular}{|c|c|c|c|c|c|c|c|c|}
\hline \multirow{3}{*}{ Density of Flies } & \multicolumn{4}{|c|}{ Diarrhea Incidence } & \multicolumn{2}{|c|}{ Total } & \multirow[t]{3}{*}{ PR } & \multirow[t]{3}{*}{ P-Value } \\
\hline & & & & & & & & \\
\hline & $\mathbf{N}$ & $\%$ & $\mathbf{N}$ & $\%$ & $\mathbf{N}$ & $\%$ & & \\
\hline Very High & 14 & 82.4 & 3 & 17.6 & 17 & 100 & $20.41(5.24-79.55)$ & 0.00 \\
\hline High & 27 & 77.1 & 8 & 22.9 & 35 & 100 & $14.76(5.66-38.48)$ & 0.00 \\
\hline Moderate & 11 & 28.2 & 28 & 71.8 & 39 & 100 & $1.71(0.71-4.16)$ & 0.33 \\
\hline Low & 16 & 18.6 & 70 & 81.4 & 86 & 100 & Comparator & \\
\hline Total & 68 & 38.4 & 109 & 61.6 & 177 & 100 & & \\
\hline
\end{tabular}

Table 4. Distribution of dairy farmers according to the relationship incidence of diarrhea with livestock waste management in Pudak Kulon Village.

\begin{tabular}{|c|c|c|c|c|c|c|c|c|}
\hline \multirow{3}{*}{$\begin{array}{l}\text { Livestock Waste } \\
\text { Management }\end{array}$} & \multicolumn{4}{|c|}{ Event Diarrhea } & \multicolumn{2}{|c|}{ Total } & \multirow[t]{3}{*}{ PR } & \multirow[t]{3}{*}{ P-Value } \\
\hline & & & & & & & & \\
\hline & $\mathbf{N}$ & $\%$ & N & $\%$ & $\mathbf{N}$ & $\%$ & & \\
\hline No & 53 & 49.5 & 54 & 50.5 & 107 & 100 & $3.59(1.81-7.14)$ & 0.00 \\
\hline Yes & 15 & 21.4 & 55 & 78.6 & 70 & 100 & & \\
\hline
\end{tabular}


or 119 breeders have not carried out the separation of sewerage channels with rainwater channels. As much as $75.1 \%$ of respondents or 133 farmers also have not made a watertight sewer, so that the permeation of livestock waste water to the ground is very likely. Livestock waste which is directly discharged into the environment without being treated first can cause air, water and soil pollution. ${ }^{11}$

As much as $60.5 \%$ of respondents or 107 dairy farmers in Pudak Kulon Village did not manage livestock waste properly, whereas in land with feces and urine content between $27-86 \%$ is the best medium for the growth and proliferation of fly larvae which is diarrhea vector. ${ }^{17}$ In addition, pathogenic microorganisms (disease causes) originating from livestock waste can pollute the environment. One of these microorganisms is Salmonella Spp which is the causative agent of diarrhea. ${ }^{11}$

Research with the same results was carried out by Anitasari in 2008, regarding the relationship between sanitary conditions of livestock pens and the incidence of diarrhea in dairy farmers in Singosari Village, Mojosongo Subdistrict, Boyolali District which showed a relationship between the use of livestock waste and the incidence of diarrhea. ${ }^{17}$

\section{Conclusions}

Based on the results of the study, the following conclusions can be obtained: (1) The rate of fly density around the cage of dairy cattle that has a very high density of 9.6\% (17 respondents), high density of $19.8 \%$ (35 respondents), moderate density $22 \%$ (39 respondents) and low density 86 respondents $(48.6 \%)$. (2) Farmers who carry out waste management well amounted to 70 respondents $(39.5 \%)$. (3) As much as $38.4 \%$ or 68 families of farmers have experienced diarrhea. (4) There is a significant relationship between the incidence of diarrhea and very high fly density ( $\mathrm{P}$ value $=0.00)$, so that the higher the density of flies, the more significant the relationship with the incidence of diarrhea. (5) There is a significant relationship between the incidence of diarrhea and waste management $(\mathrm{P}$ Value $=0.00)$

\section{References}

1. World Health Organization. Diarrhea. Geneva: World Health Organization; 2016. Available from: http://www.who. int/topics/diarrhoea/en/. Accessed on: 2 September 2016.

2. Republic of Indonesia's Ministry of Health Indonesia (Ministry of Health RI). Situation of Diarrhea in Indonesia 2011. Available from: http://www. depkes.go.id/download.php?file= download / pusdatin / buletin / bulletindiare.pdf). Accessed on: 2 September 2016.

3. Notoatmodjo S. Health Promotion and Health Behavior Jakarta: Rineka Cipta; 2012.

4. Pudak Health Center Ponorogo. Annual Report of Pudak Health Center. Ponorogo: Health Center; 2015.

5. Dewi DI. Flies and Life. Balaba: R \& D Journal of Animal-Based Disease Control 2007;4(1):18-19.

6. Wijayanti T. Vector and Reservoir. Balaba: Research and Development Ministry of Health RI 2008;2(18):1819.

7. Manulu M, Marsaulina I, Ashar T. Relationship between the level of fly density (Musca domestica) and the incidence of diarrhea in toddlers in settlements around the final garbage dump Namo Bintang, Pancur Batu Subdistrict, Deli Serdang District, 2012. Journal of Environment and Occupational Health 2012;2(1):1-10.

8. Sugiyono. Quantitative, Qualitative and R \& D Research Methods. Bandung: Alfabeta; 2015.

9. United States National Library of Medicine. Diarrhea2016. Available from: https://medlineplus.gov/diarrhea. html. Accessed on: 13 November 2016.

10. Al-Gallas N, Bahri O, Bouratbeen A, et al. Etiology of Acute Diarrhea in Children and Adults in Tunis, Tunisia, with Emphasis on Diarrheagenic Escherichia coli: Prevalence, Phenotyping, and Molecular
Epidemiology. The American Journal of Tropical Medicine and Hygiene 2007; 77(3):571-582.

11. Widyastuti FR, Purwanto P, Hadiyanto H. Environmental Management Efforts of Cattle Farming in the Integrated Farming Area of Bangka Botanical Garden Pangkalpinang. Paper presented at the 2013 National Seminar on the Management of Natural Resources and the Environment 2013. Available from: http://eprints.undip.ac.id/40627/1/012_Fianda_Revina_Widyastuti.pdf. Accessed on: 11 January 2017.

12. Ministry of Environment. Regulation of the Minister of Environment No. 11 of 2009 concerning Wastewater Quality Standards for Cattle and Pig Businesses and / or Activities. Jakarta: Ministry of Environment; 2009.

13. Hongkong Environmental Protection Department. Code of PracticeLivestock Waste Management 2016. Available from: http://www.epd.gov.hk/ epd/sites/default/files/epd/english/envir onmentinhk/waste/guide_ref/files/all.p df. Accessed on: 17 May 2017.

14. Abdurahman D. Biology: Agricultural and Health Group Bology Textbooks for Class XI Vocational Schools. Bandung: Grafindo Media Pratama; 2008.

15. Lidya M, Muliani R. Health Epidemiology: Research Approach. Yogyakarta: Graha Ilmu; 2010.

16. Adler SC. Environmental Indicators of Infections in Rural Areas and Urban Slum of Vellore, India. Boston: Tufts University; 2010.

17. Anitasari P. Relationship Between Condition of Sanitation of Animal Cages and Diarrhea in Dairy Farmers in Singosari Village, Mojosongo Subdistrict, Boyolali District 2008. Available from: http://v2.eprints. ums.ac.id/archive/etd/2746. Accessed on: 17 May 2018 